\title{
Characterisation and Classification of Tribunals and Inquiries in Nigeria
}

\author{
By M. Olu Adediran
}

The period between 1960 and 1966 witnessed the consolidation of the administrative gains of the colonial era. There was the trial of emerging a solid political foundation for the new independent state. The administration was involved more on political consolidation, rather than administrative organisation, in terms of setting up tribunals and inquiries. In fact, during that period, only few notable inquiries/commissions were set up. ${ }^{1}$ There was little or no social administrative tribunal set up during this period.

The first take-over of government by the military in 1966, saw an avalanche of tribunals and inquiries. In order to justify its take-over of government, the military set up inquiries into nearly all areas of administration in order to detect fraud, impropriety, and reorganise the various areas of administration that were found decaying or plagued with fraud and inaptitude. There were inquiries into all the Corporations which had been performing below expectation; there were inquiries into statutory councils, parastatals, corporate bodies and the civil service. The focus was on the various sectors of administration aimed at energising them into better productivity.

The tribunals set up in this period focussed on the assets of the politicians and public of fice holders who were suspected to have unjustly enriched themselves at the expense of the public. That was the first time when citizens faced charges of fraud or corruption before bodies outside the normal court system. One thing to note during this period was the fact that the initiative of setting up these bodies came from the new military government, which was concerned with cleansing the decaying society.

The period between 1979 and 1983 (Second Republic) inherited the previous system of tribunals and inquiries, with more emphasis on inquiries. The bulk of inquiries centred on fraud and financial improprieties committed by political office holders of the period. Even many of the fire disasters on which inquiries were set up could not be exonerated from being linked with fraud. In fact, those inquiries could have been avoided of the govern-

1

Commission of Inquiry into the National Bank of Nigeria 1961, Commission of Inquiry into some Corporations in the Western Nigeria 1962, Inquiry into the Affairs of West African Examinations Council 1965. 
ment was not privy, by act of omission, to fraud and financial mismanagement for which the regime was noted.

Unlike under the previous military regime, which initiated inquiries, the second Republican government felt unconcerned in many instances, until reactions were mounted up by the citizens. It was pressure from the populace that actually led to some inquiries being set up to look into the causes of various calamitous incidents of the era.

It is however worthy of note that some tribunals that were set up by the first military regime to perform some strictly judicial functions, ceased to function, by virtue of the 1979 Constitution. For example, the Rent Tribunals set up under the various Rent Edicts of the States, the Robbery and Fire Arms Tribunals, the Exchange Control (Anti-Sabotage) Tribunals, the Forfeiture of Assets Tribunals, all had their functions taken over by the courts established under the 1979 Constitution.

The second coming of the military in December 1983 witnessed the return of tribunals. The corruption, looting of the public treasury and administrative ineptitude that witnessed the Second Republic were unequalled in the country's history; the military that took over swang into action immediately by setting up tribunals to clean the body politic. Tribunals were set up to perform those functions that belonged to the courts, with the power to apply stiffer penalties for offences that were already recognised by the law. Even where such offences were being prosecuted in the courts, they were transferred to the tribunals. ${ }^{2}$ It is worth noting that the setting up of public inquiries drastically reduced with the second coming of the military. Instead, the number of tribunals increased tremendously.

Generally, it is an onerous task to classify these tribunals and inquiries, as they have their functions and purpose over-lapping with one another. There has been no effort at evolving a clear cut picture which will make them identifiable, either due to their names or functions. however, there is a little attempt at present to identify the nature of the particular body as to whether it is intended to be strictly a tribunal, performing judicial functions like the courts or as a fact finding one, set up to make recommendations to a higher body. This does not mean, that even where strictly judicial function is being performed, decisions are final. In fact most judicial tribunals take decisions which are subject to the ratification by the highest executive body (e.g. the Armed Forces Ruling Council).

There have been problems on what the words 'tribunal' and 'inquiry' are intended to mean. A closer look at both words reveal that there is a difference, though they have been used as if they have the same meaning. When 'tribunal' is used as the last word, like 'XYZ

2

A.G. (Federation) v Ukpa Akinloye \& Anor (1984), unreported. This case was withdrawn from the Federal High Court and taken to the Exchange Control (Anti-Sabotage) Tribunal. 
Tribunal', that body is intended to be a judicial one. But where 'tribunal' is used with 'inquiry' like 'Tribunal of Inquiry into $\mathrm{ABC}$ ', that body is intended to be an investigating one. What operates in some cases may not be as clear as this. The word 'Panel', 'Commission', 'Committee' have all been used in both 'judicial' and 'investigating' functions; it is only by looking into the terms of reference that one knows the exact functions such bodies are set up to perform.

The aim of this paper is to make an attempt to broadly characterise and classify the various tribunals and inquiries as we have then today in Nigeria.

\section{Characterisation of Tribunals and Inquiries}

The characterisation can only be done through comparison of these bodies with any analogous body involved in judicial function - which is the court. One should note that courts and tribunals look alike, but courts and inquiries do not; though all can be said to be performing judicial functions.

\section{Courts and Tribunals}

\section{Creation}

As of today in Nigeria, courts are created by or by virtue of the Constitution. In this regard, Section 6 of the Constitution ${ }^{3}$ provides:

"6 (1) The judicial powers of the Federation shall be vested in the courts to which this section relates, being courts established for the Federation.

(2) The judicial powers of a State shall be vested in the courts to which this section relates, being courts established, subject as provided by this Constitution, for a State."

The Constitution goes further in Section 6(5) to mention courts that are to be created as:

"(a) the Supreme Court of Nigeria;

(b) the Court of Appeal;

(c) the Federal High Court; including the Federal High Court in the Federal Capital Territory, Abuja;

(d) a Sharia Court of Appeal of the Federal Capital Territory;

(e) a High Court of a State;

(f) a Sharia Court of Appeal of a State;

(g) a Customary Court of Appeal of a State; 
(h) a Customary Court of Appeal of the Federal Capital Territory;

(i) such other courts as may be authorised by law to exercise jurisdictionon matters with respect to which the National Assembly may make laws; and

(j) such other courts as may be authorised by law to exercise jurisdiction at first instance or on appeal on matters with respect to which a House of Assembly may make laws."

Though the National Assembly throughout its life (October 1, 1979 - December 30, 1983) did not exercise its power under an analogous 1979 Constitutional Section to Section 6 (5) (i) above, some courts that were already created for the States were deemed to have been so created by the States' Houses of Assembly by virtue of an analogous 1979 Constitutional Section to Section $6(5)$ (j). Such courts are the Magistrates Courts, ${ }^{4}$ District Courts, ${ }^{5}$ Customary Courts ${ }^{6}$ and the Area Courts ${ }^{7}$.

It is pertinent to note that before the 1960 Constitution, courts as existed in Nigeria were created by statutes; that Constitution, and the subsequent 1963 Constitution only recognised and recreated them. It can therefore be said that the Nigerian courts are a creation of Statutes ${ }^{8}$ and the Constitutions.

Tribunals, as existing today, are created by various statutes. ${ }^{9}$ It can however be said that they are recognised by the Constitution for purposes of exercising judicial functions. The right to fair hearing entrenched in Section 35 of the 1989 Constitution extends to a person appearing before tribunal established by law. ${ }^{10}$ Such a person must have the benefit of having his matter adjudicated before the tribunal in public except in certain circumstances. ${ }^{11}$ With the word 'tribunal' mentioned in Section 35 of the Constitution, though it is not created like the courts, it is recognised.

4

Established by the Magistrates Court Law, Cap. 82, Laws of Eastern Region, 1963 (applicable in Anambra, Imo, Cross Rivers,Rivers, Akwa Ibon States), Magistrate Courts Law, Cap. 74, Laws of Western Region, 1959 (applicable in Oyo, Ogun, Ondo and Bendel States).

5 Established by the District Courts Law, Cap. 30, Laws of Northern Region, 1963 (applicable in all the Northem States).

6 Established by Customary Courts Law, Cap. 31, Laws of Western Region, 1959 (for those States carved from Western Region), The Customary Courts Law, Cap. 32, Laws of Eastern Region, 1963 (for those States carved from Eastern Region).

7 Created by Native Courts Law, 1956. The Native Courts were changed by various Edicts to Area Courts as they exist today by the Military Governments. See the High Court Law, Cap. 44, Laws of Western Region, 1959; High Court Law, Cap. 61, Laws of Eastern Region, 1963; High Court Law, Cap. 49, Laws of Northern Region, 1963 etc.

9 See their statutes under types of tribunals.

10 S. 35 (1) and (4).

11 S. 35 (12). 


\section{Permanence}

By nature, courts are of a more permanent nature than tribunals. Since some courts are specifically mentioned by the Constitution, they can only be changed by amending the Constitution through the cumbersome procedure provided under Section 10 thereof. However, the Constitution, through Section 6 (4), vests power on the House of Assembly to abolish some state courts of found to be unnecessary. As for the abolition of other Federal courts, the Constitution has to be amended. This guarantees their permanence, as the procedure for amending the constitution is cumbersome. Tribunals having been created by statutes can be abolished by another statute when deemed necessary. It does not take more than following the procedure of ordinary law making.

It should be noted, that some tribunals are more permanent than others. For example, those tribunals that are to be established in relation to the professions, ${ }^{12}$ are more permanent than the ad hoc 'judicial' tribunals, ${ }^{13}$ which are established to perform courts' functions. The latter tribunals, being created by the military are subject to erratic creation and abolition. As for the former, they can only be abolished, if the creating statutes are so repealed, but since established they have never been abolished.

\section{Determination of Controversy}

Both the courts and tribunals determine disputes between two or more contending parties. In other words, they exercise jurisdiction only when there is a lis inter partes. The jurisdiction of the courts cannot be invoked unless there is a controversy which is to be settled. The Constitution is specific on this, when it provides under Section 6 (6) thus:

"The judicial powers vested in accordance with the foregoing provisions of this section (a) shall estend, notwithstanding anything to the contrary in this Constitution, to all inherent powers and sanctions of a court of law;

(b) shall extend to all matters between persons, or between government or authority and any person in Nigeria, and to all actions and proceedings relating thereto, for the determination of any question as to the civil rights and obligations of that person, and accordingly, the doctrine of State immunity in respect of liability in tort no longer applies.

Before the jurisdiction of tribunals is also invoked, there must be a dispute or controversy either civil or criminal that the tribunal will adjudicate upon. For example, before the

For example Legal Practitioners Disciplinary Committee, Medical and Dental Practitioners Disciplinary Tribunals etc.

For example Armed Robbery and Fire Arms Tribunals, Exchange Control (Anti-Sabotage) Tribunals, Public Officers Protection Against (False Accusation) Tribunals etc. 
Professional or Domestic Tribunals like the Legal Practitioners Disciplinary Committee or the Medical and Dental Practitioners Disciplinary Tribunal can exercise jurisdiction, there must have been allegations of professional misconduct against a professional, which the Tribunal is called upon to adjudicate. So also, is the Industrial Relations Tribunal like the Industrial Arbitration Panel, constituted to settle dispute either in relation to wages, awards, pensions, gratuities etc., between workers and their employers.

\section{Composition}

Courts are normally presided over by legally trained personnel, whereas this may not be so for tribunals. The Constitution recognises the age long practice of allowing only judges to preside over courts of law; and it has provided this in various sections. Profession qualifications are provided for those who will preside in the Supreme Court, Court of Appeal, Federal High Court, High Court of a State, Sharia Court of Appeal and Customary Court of Appeal. As for the lower courts, only the lower Area and Customary Courts may not be presided over by legally trained persons. The qualification here is the knowledge of the customs and traditions of the area concerned. In some States, lay-men may be appointed to function as lay magistrates, in order to assist in decongesting the courts and fill judicial vacancies that professionals refuse to take up. The fear that justice may not dispensed in the courts presided over by lay-men, is minimised by constant administrative review of their cases by the various Chief Judges and the opportunity for appeal to higher courts presided over by professionals.

Though for dispensation of justice, it is now the practice to make professions chairmen of tribunals, there are still many tribunals presided over by lay-men, who are well knowledgeable in the matter for which the tribunal is set up. For example, the chairman for the professional tribunals apart from the Legal Practitioners Disciplinary Committee, need not and are not legally trained. Chairmen of tribunals set up by Ministers under some statutes $^{14}$ need not be lawyers. However, to ensure justice and fair play, such tribunals always have legally trained persons as members. This is necessary, since interested parties may be represented by legal practitioners, whose language can only be understood by members of their profession.

The Military Government, under General Buhari, abused the long tradition, when it made lay-men chairmen of judicial tribunals that were set up to try public officer under the Recovery of Public Property (Special Military Tribunals) Decree No. 3, 1984. In spite of the stiff opposition by the Nigerian Bar Association, a High Court judge was only made an ordinary member of the tribunal. The situation was reversed by the Babangida government

14 For example under Chiefs Law, Cap. 21, Laws of Oyo State, 1978, Section 36, Cooperative Societies Law, Cap. 21, Laws of Oyo State, 1978, Section 23, Trade Disputes Act 1976 etc. 
by promulgating the Recovery of Public Property (Special Military Tribunals) (Amendment) Decree No. 21, 1986, which made High Court judges preside over such tribunals.

\section{Imposition of Obligations}

The courts impose obligations upon individuals appearing before them whereas tribunals may not. The earlier cited Section 6 (6) (a) and (b) of the 1989 Constitution empowers the courts to determine and make pronouncements on issues between persons or between persons and authorities. This power includes the making of specific orders which must be carried out. Section 44 of the Constitution is even more specific as to this power when it provides: ${ }^{15}$

"Subject to the provisions of this Constitution, a High Court shall have original jurisdiction to hear and determine any application made to it in pursuance of the provisions of this section and may make such orders, issue such writs and give such directions as it may consider appropriate for the purpose of enforcing or securing the enforcement within that state of any rights to which the person who makes the application may be entitled under this Chapter."

By virtue of Sections 6 (6) (b) and 44 (2) of the 1989 Constitution, the courts have overwhelming powers to give binding orders which must be obeyed. ${ }^{16}$. This judicial force cannot be generally true of tribunals. Tribunals, such as Industrial Arbitration Panel, National Industrial Court, Rent Tribunals, professional (domestic) tribunals, normally impose obligations on parties, which must be carried out, until set aside by superior court (High Court), but there are other tribunals, such as statutory ones under the Chiefs Law, Cooperative Societies Law, Trade Disputes Acts etc., that merely make recommendations which may or may not be accepted by the appropriate authority.

\section{Finality of Decisions}

Courts' decisions are final and conclusive. They are binding and remain in force and they are not subject to any legislative or executive ratification. They continue to have effect as such until an appellate court overturns them. Though decisions of some tribunals may be final, such may be rendered nuggatry by the executive, by constituting a new set of people

15

16

Section 44 (2).

In Military Governor of Lagos State \& Ors v Chief Emeka Odumegwu Ojukwu, (1986) 2 S.C. 277, Obaseki JSC held (at page 281): "Once a dispute has arisen between a person and the government or authority and the dispute has been brought before the courts, thereby invoking the judicial powers of the state, it is the duty of the government to allow the law to take its course or allow the legal and judicial process to run its full course." 
to determine the same issue. The 'judicial' tribunals ${ }^{17}$ set up after the Second Republic did not take binding and conclusive decisions. They only made recommendations to the Armed Forces Ruling Council which has the power to ratify, reject or vary their decisions. A common provision in the various Statutes was that which provided:

"Any sentence imposed or awarded by the Tribunal shall be subject to confirmation, variation of disallowance by the Supreme Military Council (Armed Forces Ruling Council) and if confirmed, varied or disallowed, the sentence shall not thereafter be liable to review or be the subject of an appeal."

This provision was regarded as unfair, hence stiff opposition by the populace resulted in the promulgation of the Recovery of Public Property (Special Military Tribunals) (Amendment) Decreee No. 21, 1986, which established Special Appeal Tribunal to handle the various appeals from the judicial tribunals.

\section{Rules of Evidence}

Proceedings in courts are governed by rules of evidence and the appropriate rules of courts; tribunals on the other hand are not bound by rules of evidence except the statute provides such. The essential qualification is that they must act fairly in their deliberations. They have power to arrive at their decisions in any way they feel appropriate, without a strict adherence to any procedure or rules of evidence, but the rules of fair hearing must be followed. ${ }^{18}$ Lord Loreburn L.C. aptly described the conduct and powers of members of tribunals when he said:

"... they must act in good faith and fairly listen to both sides. But I do not think they are bound to treat such a question as though it were a trial. They have no power to administer an oath, and need not examine witnesses. They can obtain information in any way they think best, always giving a fair opportinity to those who are parties in the controversy for correcting or contradicting anything prejudicial to their view." ${ }^{19}$

Though tribunals are not bound by rules of evidence, the fact, that they are presided over by legally trained persons and the fact, that lawyers are always present to represent parties, have accounted for a sort of procedure that is not totally different from what operates in the regular courts.

Recovery of Public Property (Special Military Tribunals), Special Tribunal (Muscellaneous Offences), Exchange Control (Anti-Sabotage) Tribunal, Public Officers (Protection Against False Accusation) Tribunal, Armed Robbery and Firearms Tribunals etc.

Section 35 (1), 1989 Constitution of Nigeria.

19

Board of Education v Rice, (1911) A.C. 179.

20 For example proceedings in Rent Tribunals, Industrial Arbitration Panel and Industrial Court look exactly like those of the courts. 


\section{Superiority of Courts}

Superiority is conferred on the courts by the Constitution, whereas tribunals are regarded as "inferior". In this regard, Section 6 (3) of the Constitution provides:

"The courts to which this Section relates established by this Constitution for the Federation and for States specified in Sub-section (5) (a) to (j) ${ }^{21}$ of this Section shall be the only superior courts of record in Nigeria; and save as otherwise prescribed by the National Assembly of by the House of Assembly of a State, each court shall have all the powers of a superior court of record."

Apart from the 'judicial' tribunals, where appeals lie to the Special Appeal Tribunal and the Armed Forces Ruling Council, all other tribunals, whatever name called, are regarded as inferior and where a party is not satisfied with their decisions, he may appeal to a High Court having original jurisdiction over the matter.

\section{Designated Venue of Sitting}

Courts normally sit in places designated as such either by instrument or by the direction of the Chief Judge; tribunals may conduct their proceedings at any place that is convenient. They may even move from one location to the other; their decision will not be vitiated for failure to sit in a designated location.

The above comparison brings out the characteristics of tribunals in relation to courts, other characteristics can only be appreciated if tribunals are compared with inquiries. As said earlier, 'inquiries' share similarities with 'tribunals', but not courts.

\section{'Tribunals' and 'Inquiries'}

A starting point is to examine the use of the two words - 'tribunals' and 'inquiries' whether they mean the same thing or mean two different things. The administration has added confusion to the appropriate meaning of the words by using them interchangeably or even together at times, as if they mean the same thing.

When inquiries are set up to investigate matters of public interest, the normal practice is to name them "Inquiry into ABC", "Judicial Panel of Inquiry into XYZ", "Tribunal of Inquiry into ZYX", "BBC Tribunal of Inquiry", "Commission of Inquiry into JAC", "Panel of Inquiry into MIC". There has been no noticeable uniformity in the use of the words 'tribunals' and 'inquiries'. 'Tribunals' in its legal term means body or body of persons set up 
to perform a function which is judicial in nature, while 'inquiry' means investigation. Where the administration join both words, they mean to say a body of persons set up or constituted to investigate a matter. Both words may precede matters to be investigated as in "Tribunal of Inquiry into the Importation of Cement" or succeed such matter as in "Kano Disturbances Tribunal of Inquiry". Whatever be the arrangement, such body is constituted to investigate matters under reference.

When the word 'tribunal' is used without 'inquiry', the intention is to constitute such body as a judicial or quasi-judicial one, which is permanent or ad hoc, with the duty of making a binding decision, using facts and the law. Though, some tribunals may perform recommendatory functions, many take final decisions. There is therefore less confusion by the use of 'tribunal', which normally succeeds the subject matter as in Medical and Dental Practitioners Disciplinary Tribunal, Rent Tribunals, Recovery of Public Property (Special Military Tribunals) etc. From their titles, they are intended to be 'special courts' set up to perform special functions.

Having cleared the issue of usage of both words, it is now necessary to look at the characteristics of inquiries vis-a-vis those of tribunals that are closely related.

\section{Permanence}

As noted above, some tribunals are permanent by nature; inquiries are never permanent no matter the duration of their assignment. They are merely set up to investigate matters, and after submitting their reports, they cease to exist. In fact, their life span is always provided in the instruments setting them up. Depending on the nature of matters under investigation inquiries may last between four to eight weeks. ${ }^{22}$ Where matters are not concluded within the time limit, extension is always granted.

\section{Empowering Statute}

While tribunals are constituted under different statutes, all inquiries are set up under the same enactment. Tribunals, constituted for different purposes, are so constituted under separate enactments which are made for such purposes only. For example, only Rent Tribunals can be constituted under the Rent Edicts, and only professional tribunals, like the Legal Practitioners Disciplinary Tribunal, can be constituted under their enactments. 23

For example the University of Ife Students Hostel Incident Tribunal of Inquiry 1981 - four weeks; Kano Disturbances Tribunal of Inquiry 1981 - four weeks; Commission of Inquiry into the Com23 munial Disturbances in Oranmiyan Central Local Government Area 1980 - four weeks.

See Legal Practitioners Act 1975. 
Inquiries, on the other hand, are set up, by instruments, under the power conferred by a single enactment - Tribunals of Inquiry Act. ${ }^{24}$ Section 1 of the Act Provides:

"The Head of the National Military Government (in the Decree referred to as 'the proper authority') may, whenever he deems it desirable, by instrument under his hand (hereafter in this Decree referred to as 'the instrument') constitute one or more persons (hereafter in the Decree referred to as 'member' or 'members') a tribunal to inquire into any matter or thing or into the conduct of affairs of any person in respect of which in his opinion an inquiry would be for the public welfare. The proper authority may by the same instrument or by an order appoint a secretary to the tribunal who shall perform such duties as the members shall prescribe."

Though the States have their own inquiry laws, ${ }^{25}$ the Federal government through Tribunals of Inquiry (Amendment) Act of $1977^{26}$ later empowered the State Governors to constitute inquiries in their States and where they had done so without authority, such were validated. ${ }^{27}$ Therefore, whenever an inquiry is to be set up, the "proper authority" will do so under either the Tribunal of Inquiry Act of 1966 or any State Law in respect thereof.

\section{Defined Jurisdiction}

Tribunals normally have defined jurisdictions under their statutes which must be strictly adhered to, otherwise the court may invoke the doctrine of ultra vires against them. The jurisdiction of inquiries are also limited by the terms of reference, set out by the instruments consisting them. Though, inquiries may be challenged in court before, during or after sitting, in case they investigate ultra vires matters, where such challenge is not made, the appointing authority may only disregard their findings on those ultra vires matters.

\section{Lis inter partes}

Tribunals are constituted to perform judicial functions or whether settling disputes between two or more contending parties or act as a disciplinary body. Their decisions may be final on the issue and can only be challenged in superior court. Inquiries, though, must be fair in their investigation, are set up to find facts in relation to a matter. The primary purpose of an inquiry is:

No. 41 of 1966. This Act replaces the Commissions and Tribunals of Inquiry Act, No. 26 of 1961.

See Commissions of Inquiry Law, Cap. 25, Laws of Northern Nigeria, 1963; Commissions of Inquiry Law, Cap. 23, Laws of Western Nigeria, 1959, etc.

Tribunals of Inquiry (Amendment) Act No. 2, 1977.

Tribunals and Inquiries (Validation etc.) Act (Decree) No. 18, 1977. 
"to satisfy the public that a proper investigation has been made into a matter about which there is a great deal of public disquiet." 28

\section{Rules of Evidence}

Tribunals, as judicial or quasi-judicial bodies, conduct their proceedings judicially. Though they are not expected to follow rules of evidence strictly, the fact that legally trained persons preside over some of them and the fact that parties are legally represented before them, tend to make their procedure akin to that of the court. The procedure may be adversary sometimes. The conduct of an inquiry is less formal than that of tribunal. Evidence may be obtained anyhow. The rules in relation to admissibility of evidence are disregarded. The inquiry is set up to find facts about a matter, any method used, short of being illegal, is allowed. While there are marked interests before tribunals, either as complainant or defendant, people appearing before an inquiry, are witnesses for the inquiry whether allegations are made against them or not, or whether they appear on their own volition or they are subspoenaed. Such witnesses may also be legally represented. ${ }^{29}$

\section{Composition}

A tribunal may be constituted by a single individual so also an inquiry. However, the general practice is to have a body of persons, generally three, as members to conduct an inquiry.

\section{Publicity}

The setting up of an inquiry is always preceded by publicity through the print and electronic media. Members of the public are notified of the inquiry and are requested to submit memoranda and be ready to give oral evidence, if necessary. The sitting is in a public place with journalists and the public in attendance. The day to day hearing is usually disseminated to the public through the print and electronic media. This should normally be the practice since the administration want to satisfy the public that something is being done about the matter under inquiry; the reassuring procedure is to publicise the hearing.

Though tribunals sit in public, this type of publicity is absent. Only the parties and their representatives will know of the date, time and venue of the hearing. It must be noted that 
where necessary the public may be disallowed attendance at some sittings of inquiries, especially when evidence on matters of security are to be tendered. This reason apart, the public is normally sceptical about the result of an inquiry when they are precluded from attending the sitting, for no justifiable reason. 30

\section{Classification of Tribunals and Inquiries}

\section{Tribunals}

Tribunals, sometimes called administrative tribunals, are quasi-judicial bodies established by the administration to provide solutions to administrative problems. Matters taken to them are such that could have gone to the ordinary courts, but since the administration needs quick solution to such problems, they are better tackled by tribunals. By nature, therefore, tribunals provide simpler, speedier, cheaper and more accessible justice for citizens than the courts.

In England, tribunals were first established for welfare schemes, where there were complaints, objections and claims to be settled. The courts process was deemed elaborate, slow and costly and a clog in the wheel of welfare programmes. It was therefore considered necessary to establish bodies that could effectively handle such quasi-judicial matters within the administration, hence they are called "administrative" tribunals. England has utilised this administrative machinery to cover areas of personal welfare, ${ }^{31}$ service pensions, ${ }^{32}$ education, ${ }^{33}$ economic, ${ }^{34}$ transport, ${ }^{35}$ housing, ${ }^{36}$ taxation, ${ }^{37}$ and rating. ${ }^{38}$ Nigeria does not boast of this type of expansion, but since the society is still developing, such future expansion is still possible.

30

The Profumo Affair investigated by Lord Denning in secret was only accepted because of the personality of the Lord. The public was not surprised of the outcome of Crude Oil Sales Tribunal of Inquiry chaired by Justice Ayo Irikefe, since all media were disallowed to make independent report except through the medium controlled by the Federal Government.

e.g. Medical Appeal Tribunals, National Insurance Local Tribunals, Supplementary Benefit Appeal Tribunals etc.

33

e.g. Nurse's Training Institution Appeal Tribunal, Independent Schools Tribunal.

34 e.g. the Traffic Commissioners, The Transport Tribunals etc.

e.g. Rent Tribunals, Rent Assessment Committee etc.

e.g. Industrial Tribunals, Supplementary Benefit Appeal Tribunals etc.

e.g. Local Valuation Courts, Land Tribunals etc. 
The only meaningful classification of tribunals that can be made in Nigeria is according to the subject matter. Tribunals are set up for different purposes and such purposes will indicate their classification. It must be admitted that some tribunals may qualify to belong to more than one class, the classification attempted is therefore general.

\section{Social Services and Economic Tribunals}

As indicated above, Nigeria does not boast of the English-type of numerous tribunals established for welfare purposes. The level of societal development accounts for this. In fact the setting up of tribunals was a post 20th century phenomenon in Britain. Be that as it may, there are few tribunals established for social services in Nigeria also.

The Rent Tribunals were established under the various Rent Control Edicts to peg the skyrocketing rents that witnessed the post-70 oil boom era. The Edicts zoned urban residential areas and determined rents payable for each zone. The Tribunals were established to settle conflicts between landlords and tenants on the one hand, and enforce the Rent Edicts on the other hand. Such tribunals were presided over by legally trained persons, with other two persons each representing the landlord or the tenant interests. ${ }^{39}$

The Price Control Boards were also established at the same time to regulate the prices of goods that were getting beyond the reach of the consumers. ${ }^{40}$ Members of the Board were given power to regulate and enforce prices of goods. Offenders were prosecuted in the High Court.

\section{Industrial Relations Tribunals}

The Trade Disputes Act ${ }^{41}$ established two important tribunals to settle trade disputes between workers and their employers. The first is the Industrial Arbitration Panel established under Section 7 to settle disputes referred to it. The second is the National Industrial Court which is established under Section 14 (1) of the Act to settle disputes which the Industrial Arbitration Panel cannot resolve. This court has jurisdiction in respect of "settlement of collective trade disputes, the interpretation of collective agreements and matters connected therewith". In this connection Section 15 (1) provides:

See Lagos State Rent Control and Recovery of Residential Premises Edict No. 9, 1976; Bendel State Rent Edict No. 4, 1977; Cross River State Rent Edict No. 8, 1977; Plateau State Rent Edict No. 3, 1977 etc. Price Control (Amendment) Decree No. 10 of 1974).

No. 7, 1976. 
"The court shall, to the exclusion of any other court have jurisdiction -

(a) to make awards for the purpose of settling trade disputes, and

(b) to determine questions as to the interpretation of -

(i) any collective agreement,

(ii) any award made by an arbitration tribunal or by the court under Part I of this Decree,

(iii) the terms of settlement of any trade dispute as recorded in any memorandum under Section 6 of this Decree."

By Section 10 (2) of the Act, the decision of the court is final without prejudice to any appeal to the High Court.

\section{Domestic (Professional) Tribunals}

Professional bodies are empowered to regulate the practice of their professions by setting up tribunals to discipline members, who have contravened the ethics of such professions. There are the Legal Practitioners Disciplinary Committee, ${ }^{42}$ the Medical and Dental Practitioners Disciplinary Tribunal, ${ }^{43}$ disciplinary tribunals relating to the professions of Architecture, ${ }^{44}$ Engineering, ${ }^{45}$ Nursing ${ }^{46}$ and so on.

These tribunals only have jurisdiction over their respective professionals. Where allegations of professional misconduct are made against members, such are investigated by the tribunals and where found proved, appropriate disciplinary measures are taken against such professionals. They may be suspended for a period or if the offence is grave, their names may be struck of $f$ the register of practitioners. Where misconduct amount to crimes, the appropriate state agency is invited for prosecution.

The tribunals consist mainly of the members of the professions, without prejudice to the fact that legally qualified persons may be empanelled when allegations are serious in nature.

\section{'Judicial' Tribunals}

The word 'judicial' is added to this type of tribunals not because the other types of tribunals do not act judicially, but to indicate a special class of tribunal which performs

42

43

44

45

46

S. 9, Legal Practitioners Act No. 15, 1975.

S. 12, Medical and Dental Practitioners Act, 1963.

S. 12 (1), Architect (Registration etc.) Act No. 10, 1969.

S. 19 (1), Engineers (Registration etc.) Act No. 55, 1970.

S. 13 (1), Nurses Act No. 2, 1970. 
judicial functions by adjudicating criminal offences which ordinarily only courts of law should have jurisdiction.

The tribunal is a military phenomenon, intended to try criminal offences with despatch, where strict rules of evidence and unnecessary objections normally experienced in the law courts are not allowed. It is the determination to eradicate or minimise the escalation of these criminal offences that motivated the military to set up these tribunals conferred with special powers to recommend stiffer penalties for those found guilty.

In this category are the Armed Robbery and Fire Arms Tribunals, ${ }^{47}$ the Exchange Control (Anti-Sabotage) Tribunal, ${ }^{48}$ the Public Officers (Protection Against False Accusation) Tribunal, ${ }^{49}$ the Miscellaneous Offences Tribunal, ${ }^{50}$ the Recovery of Public Properties Tribunal $^{51}$ and the Treason and other of fences (Special Military Tribunal). ${ }^{52}$

Their titles indicate the offences they are set up to try. They are presided over by High Court judges, sitting with armed forces personnel. Judgments are recommendatory in nature and can be rejected, confirmed or varied the highes Military Body - the Armed Forces Ruling Council (formally the Supreme Military Council). Persons convicted by these tribunals could appeal to the Special Appeal Tribunal. ${ }^{53}$

A recent tribunal that appears to have taken over all the criminal jurisdiction of courts is the Civil Disturbances (Special Tribunal) set up under Civil Disturbances (Special Tribunal) Decree No. 2, 1987. Though the tribunal is supposed to try offences relating to civil disturbances, a look at the enumerated offences under its schedule 1 leaves no one in doubt that jurisdiction of the court in most of the serious offences under the Criminal and Penal Codes have been taken over by the tribunal.

The most recent addition to this type of tribunal is the Transition to Civil Rule Tribunal $^{54}$ which is established to deal with all matters - civil or criminal - connected with

47

48

In existence since 1971.

S. 4 (2), Exchange Control (Anti-Sabotage) Decree No. 7, 1984.

49 S. 4, Public Officers (Protection Against False Accusation) Decree No. 4, 1984.

50

S. 2 (2), Special Tribunal (Miscellaneous Offences) Decree No. 20, 1984.

51

S. 5 (2), Recovery of Public Property (Special Military Tribunals) Decree No. 3, 1984.

52

S. 1, Treason and other of fences (Special Military Tribunal) Decree No. 8, 1976. This was established to try those persons (military or not) who were connected with the coup of February 1976 in which the Head of State and some Military Officers were assassinated.

53

S. 4, Recovery of Public Property (Special Military Tribunals) (Amendment) Decree No. 21, 1966.

54 Established by Transition to Civil Rule (Political Programme) Decree No. 19, 1987, as amended by Decree No. 9, 1989. 
the transition to the civil rule programme embarked upon by the government. Persons disqualified by National Electoral Commission can appeal to the tribunal. Offences committed by persons in relation to the transitional programme are also tried by the tribunal. $^{55}$

\section{Land Tribunals}

These are tribunals called by different names, established to settle matters connected with land use or boundaries between communities. Land, being an important heritage and asset to Nigerians, is usually a cause of community clashes, which many times claim lives. Judicial settlements in court have, instead of settling crises, added to them. Irrespective of judicial orders, communities strongly feel that the land belongs to them. Even, the Land Use Act 1978 that was supposed to solve this problem, by vesting the ownership of land on the Governor to be held in trust for the people, has had no effect on the claim of communities. Another method of resolving crises amicably therefore was the establishment of Land Tribunals. Examples of this tribunal can be seen from the former Western Region of Nigeria (now Oyo. Ogun, Ondo, Bendel) and part of Lagos States. ${ }^{56}$

Section 3 (1) of the Local Government and Community Boundaries Settlement Law of Oyo State provides:

"There shall be appointed from time to time as may be necessary, fit and proper persons to be Boundary Settlement Commissions....

(2) It shall be the duty of a Commissioner to inquire into and determine such boundaries as the Executive Council may, by order made under Section 5, refer to him for determination."

Section 11 of the same law establishes another Appeal Tribunal which handles appeals from the decision of such Commissioner. Such appeal may be lodged by the AttorneyGeneral, or a local government, a community or any other person affected by such decision.

The Land Use $\mathrm{Act}^{57}$ also established some tribunals which are to advise the appropriate authority on the use of land. Section 2 (2) establishes the Land Use and Allocation Committee to advise the Governor on:

55

56

57 No. 6, 1978.

Alhaji Balarabe Musa was being tried by the Tribunal for taking part in politics when he was supposed to have been banned.

Cap. 67, Laws of Oyo State of Nigeria, 1978; see also Local Government and Community Boundaries Settlement Law, Cap. 64; Laws of Ogun State, 1978, Section 3 (1); Local Government and Community Boundaries Settlement Law, Cap. 63; Laws of Ondo State, Section 95 (1). 
(1) any matter connected with the management of land,

(2) the settlement of persons affected by revocation of rights of occupancy, and

(3) to determine disputes as to the amount of compensation payable for improvements of land.

Section 2 (5) also establishes a Land Allocation Advisory Committee, for each Local Government to advise the Local Government on any matter connected with the management of land within the local government areas.

The membership of the Land Use and Allocation Committee is as determined by the Governor, but must consist of a legal practitioner and at least two other persons who are qualified as estate surveyors or land Officers. The membership of the Land Allocation Advisory Committee is as determined by the Governor after consultation with the local government. These land tribunals make recommendations as to the use, management and settlement of rifts over land.

\section{Election Petition Tribunals}

This is a type of tribunal which exists only during civilian regime, or when there are elections to usher in civilian regime. The first post-independent election tribunals were established by the Electoral Act of $1962 .{ }^{58}$ As a result of the take-over of government by the military in 1966, they ceased to function. They were established again in 1977, when the military was preparing to hand over government to the civilians. Section 108 (2) of the Electoral Act ${ }^{59}$ provided that there "shall be one or more election Tribunals in each state of the Federation".

The tribunal comprised of the Chief Judge of a State, or such other judge or legally qualified person as may be appointed as chairman by the Chief Justice of Nigeria, in case of election petition relating to the President or Vice-President, and two other members.

By virtue of Section 118 (1), the decision of the Tribunal on a petition is final and cannot be questioned in any court or be subject to any appeal. However, appeal could go to the Supreme Court in the case of petition arising from the Presidential election.

On the coming into force of the 1979 Constitution, the Electoral Act provisions ceased to have effect. Jurisdiction was given to the High Court of a State, by virtue of Section 237 of the Constitution:

58

No. 31 .

59 No. 73, 1977. 
"to hear and determine any question whether any person has been validly elected to any of fice or to the membership of any legislative house ..."

In the case of the office of the President or Vice-President, the Federal High Court had jurisdiction, until the coming into force of the provision (Section 262) relating to the Federal Capital Territory, when the High Court of the Territory would have jurisdiction.

The performance of the courts, in the Second Republic, as election tribunals was below expectation. Like cases, with similar facts, were decided differently, to the extent that the public lost confidence in the judiciary. ${ }^{60}$ This must have motivated the Constitution Review Committee to have suggested that election petition should be taken away from the jurisdiction of the courts. Instead, there should be established Election Tribunals to deal with election matters. In consequence of this recommendation, Section 269 of the 1989 Constitution now establishes the Presidential Election Tribunal, Governorship and Legislative Houses Election Tribunals and Local Government Election Tribunals to hear and determine petitions as to the election of the President and Vice-President, the Governors and members of the legislative, and local government councillors, respectively.

The Presidential Election Tribunal consists of a Chairman and six other members, all of whom are persons of unquestionable integrity who have not been involved in party politics. The Chairman must have held office or qualified to hold of fice as a Justice of the Supreme Court. Three of the members should also be so qualified, while the rest three members are lay-men. They are appointed by the Chief Justice of Nigeria. ${ }^{61}$

The Governorship and Legislative Houses Election Tribunal consists of a chairman and four members who are of high integrity and have not been involved in party politics. The chairman must have held or qualified to hold of fice as Justice of the Court of Appeal. Two other members must have held or qualified to hold of fice as a Judge of a High Court. The other two members shall be non-members of the legal profession. They are appointed by the President of the Court of Appeal. ${ }^{62}$

The Local Government Council Election Tribunal consists of a Chairman and two other members, who shall be persons of high integrity who have not been involved in party politics. The chairman must have or be qualified to hold of fice as a Judge of a High Court. One of the members must be a legal practitioner who has been so qualified for a period of

60

See M.A. Ajasin v. Akin Omoboriowo \& Anor, Suit No. AK/EP.1/83 of 10th Sept. 1983; J.I. Nwobodo v. C.C. Onoh, Suit No. SC96/1983; Bola Ige v. Victor Olunloyo, Suit No. EPS/1/83 of 12th Sept. 1983. 
not less than five years. The other member shall be a lay-man. Members are to be appointed by the Chief Judge of the State concerned. ${ }^{63}$

It is obvious from the establishment and composition of these tribunals that the judiciary has no part to play, save in the appointment of the members. With this arrangement it is obvious that accusation of judicial partisanship in elections will be minimal. The only role that the judiciary plays on election petitions is in its appellate jurisdiction. Appeals from the decisions of Presidential Election Tribunals lie to the Supreme Court. ${ }^{64}$ The Court of Appeal has jurisdiction to hear and determine appeals from decisions of Governorship and Legislative Houses Election Tribunals. Its decision shall be final. ${ }^{65}$ The competent High Court shall have jurisdiction to hear and determine appeals from the decisions of Local Government Council Election Tribunals. ${ }^{66}$

\section{Public Officers' Tribunals}

Bribery and corruption have always been the bane of the Nigerian society. Both contributed in no small way to the collapse of the First Republic. The vices continued to rear their ugly heads in the post civil war era, to the extent that it was felt that unless something drastic was done, the collapse of Gowon regime, was a matter of time. Rumours were rife that, the government and its agencies were neck deep in corruption. Unfortunately, the regime disregarded these rumours.

By the middle of 1975, the Gowon regime was toppled by Murtala Mohammed's military coup. The new regime, which complained of corruption as one of its reasons for overthrowing the previous regime, quickly set in motion, machineries to eradicate or minimise bribery and corruption in the Nigerian society, especially among the public officers.

The Corrupt Practices Decree (Act) ${ }^{67}$ was promulgated which made it an offence for any person, either by himself or in conjunction with any other person, to corruptly solicit or receive or agree to receive for himself or for any other person, or to corruptly give, promise or offer to any person whether for the benefit of that person or of another, any gratification or inducement or reward for something to be done for him or for any other 
person. Such person is punishable by seven years imprisonment or N 5,000.00 fine or both. $^{68}$

Section 11 (1) of the Act established as a department of the Government of the Federation, a Bureau to be known as Corrupt Practices Investigation Bureau whose duty was carry out investigation when there was reasonable suspicion that an offence had been committed under the Act.

Section 19 (1) empowered the Head of the Federal Military Government to, whenever occasion demanded, constitute one or more tribunals for the trial of offences under the Act. Such tribunal should consist of a High Court Judge as chairman and two other persons, at least one of whom must be a military officer.

Although these bodies were set up, it can not be remembered whether any public officer was ever tried for corruption under the Act. This failure must have motivated the Constitution Drafting Committee of 1976 to have re-emphasised the setting up of the bodies in the 1979 Constitution.

The 1979 Constitution prescribed a Code of Conduct for Public Officers under Schedule Five, which was aimed at minimising the rate of bribery and corruption within the society. Paragraph 15 of the Schedule created a Code of Conduct Bureau, whose main duty would be to receive declarations of assets by public officers, to examine such declarations and ensure that they comply with the requirements of the Code and of any law for the time being in force and to receive complaints about non-compliance with or breach of the Code and where the Bureau considered it necessary to refer such complaints, unless the person had made a written admission of such breach or non-compliance to the Code of Conduct Tribunal.

Paragraph 17 prescribed the establishment of a Code of Conduct Tribunal consisting of a Chairman who should have held or is qualified to hold office as a Judge of a Superior Court of record in Nigeria and two other members. The members were to be appointed by the President on the recommendation of the Federal Judicial Service Commission. They were to serve till the age of 70 years. The Tribunal was to try persons for contravention of the Code of Conduct.

In spite of this bold attempt by the Constitution, it is sad to note that neither body was established throughout the Second Republic. It was not strange therefore that that regime was branded the most corrupt civilian regime Nigeria has ever had. 
Early 1989, the Military regime promulgated the Code of Conduct Bureau and Tribunal Decree $^{69}$ which established the Code of Conduct Bureau and Code of Conduct Tribunal, in accordance with the provision of Part I of the Fif th Schedule of 1989 Constitution. The minor difference in the Decree and the provisions of the Constitution is in the number of membership of both bodies. The Code of Conduct Bureau would consist of a Chairman and ten other persons, who should be men of unimpeachable integrity in the Nigerian society. Members should not be less than 50 years and should vacate of fice at the age of 70 years. It is the duty of the Bureau to refer complaints about non-compliance with declaration of assess, to the Code of Conduct Tribunal.

The Code of Conduct Tribunal consists of a chairman who should have held or is qualified to hold of fice as a judge of a superior court of record and four other persons. They would hold office until the age of 10 years. The Tribunal is to try persons who have contravened the Decree which contains anti-corrupt practices provisions. ${ }^{70}$ The 1989 Constitution has incorporated into it the Code of Conduct Bureau, in its 3rd Schedule and Code of Conduct Tribunal under paragraph 16 of its 5 th Schedule.

\section{Departmental Tribunals}

There are numerous tribunals that are allowed to be set up in the various departments, by the administration. ${ }^{71}$ The enabling Acts normally grant this power, so as to either assist the administration in taking decisions, or to solve internally, matters that could have ended up in the court room. Decisions of such tribunal may be recommendatory or final within the administrative set up, without prejudice to the High Courts' power of review when challenged by an aggrieved party.

The tax enactments of various jurisdictions allow tribunals, under different names, to be set up to review any tax assessment done under the enactments. Bodies like Assessment Authority, Board of Commissioners, Tax Boards, Joint Tax Board, and Native Authority are tribunals which perform quasi-judicial functions in tax assessment. ${ }^{72}$

69

70

71

72

No. 1, 1989.

Both bodies have been constituted by the President and the Commander-in-Chief of the Armed Forces.

See Road Traffic Licensing Authorities set up under Cap. 113, Laws of Western Nigeria, 1959; Liquor Licensing Tribunals set up under Cap. 71, Laws of Lagos State, 1973 etc.

See generally Finance Law, Cap. 53, Laws of Eastern Nigeria, 1963; Income Tax Law, Cap. 48 of Western Nigeria, 1959; Personal Tax Law, Cap. 94, Laws of Northern Nigeria 1963; Income Tax Act, Cap. 85, Laws of Nigeria, 1958; Company's Income Tax Act, 1961; Income Tax Management Acts, 1961-1966. 


\section{Inquiries}

Inquiries have not been legally defined as such; the only definition there is, is merely descriptive and given by Wraith and Lamb as:

"well-publicized inquisitions on the grand scale which may not be concerned with government policy and administration only but for the most part, with the investigation of suspected impropriety or negligence in public life." ${ }^{73}$

From that definition, it is evident that inquiries are set up to investigate allegations of impropriety, negligence and at times to find facts in relation to a policy that is to be adopted by the administration. What marks them distinctly is their public nature. They are well publicised and their procedure is inquisitorial. They do not take final decisions but merely make recommendations, in consequence of their findings, to the appropriate authority.

In Nigeria, the number runs into hundreds but they are tucked away in the various cabinet offices, and the exact figure is yet to be known. Power to constitute inquiries is derived from the Tribunals of Inquiry Act 1966 and the various Tribunals of Inquiry Laws in the States. $^{74}$ Like tribunals, classification of inquiries is according to their nature than purpose.

\section{Administrative Policy Inquiries}

Nigeria, being a developing country, normally has problems in taking some administrative policy decisions, especially those that are political in nature, where the multi-ethnic nature of the country ought to be taken into consideration. Such decisions are not normally taken without the input of the public. Hence, whenever they are to be, inquiries are normally set up where the public will have their say.

The location of the new Federal Capital was preceded by a public inquiry - Panel on the Location of the Federal Capital (1975). When new States were to be created, because of its sensitive nature, there was an inquiry ${ }^{75}$ set up, which gathered evidence from all over the country, before that decision was taken. The creation of more Local Government Councils in Oyo State in 1980 was preceded by an inquiry - Commission of Inquiry into the creation of more local government councils in Oyo State. 
Such inquiries may also be set up to advise the administration in taking an important economic policy. For example in 1973, the increment in the salaries of workers in the public service was preceded by Public Service Review Commission. Before this there had been the Salary and Wages Commission, in 1970 set up for the same purpose. In the same vein, decision on Revenue allocation which has always been a highly volatile political issue in Nigeria was not taken until the Revenue Allocation Commission gave its report in 1980, when the government decided to review the existing formular. The participation of the public in these inquiries gave them the satisfaction that the policies that emerged therefrom had their input.

The administration may constitute such inquiry to assist in finding the causes of the inefficiency of some parastatals and proffer solutions thereto. This type of inquiry has been set up in nearly all the public corporations in Nigeria. ${ }^{76}$ Few reorganisations in the Corporations normally follow the inquiries, but this has regrettably had no effect on the precarious inefficiency.

\section{Land Matters Inquiries}

Nigeria, being an agrarian country where about $90 \%$ of her population depends on agriculture, has land as her greatest asset. Apart from this, land is needed for residential and the growing industrial purposes. By tradition, land belongs to the communities which can share it among the families for use. The greatest calamity that can befall a community is to have its land taken over by another community. In spite of the Land Use Act 1978 which now vests land on the Governor to hold in trust for the public, rural dwellers still guard jealously their right to the land.

Lives and properties have been lost as a result of clashes of communities over land. Judicial settlement is regarded as time and money wasting and unsatisfactory, the use of selfhelp is always resorted to. One of the methods used by the administration to diffuse tension and ascertain ownership is the setting up of inquiries, where communities will have the opportunity to present their case without any hinderance and with litte or no cost. $^{77}$

76 Inquiry into the Affairs of West African Examination Council, 1965; The Nigerian Railway Corporation Tribunal of Inquiry, 1968; Nigeria Airways Tribunal of Inquiry, 1960; Authority Tribunal, 1967 etc.

77 Examples are Commission of Inquiry into Sapele Urban District (Okpe Communal Lands) Trust, 1963; Commission of Inquiry into the Warri Divisional (Itsekiri Communal Lands) Trust, 1963. 


\section{Chieftaincy Inquiries}

Like Land, chieftaincy is another keenly contested traditional matter in Nigeria, especially in the Southern part. It is not unusual for bloody clashes to occur between contesting parties, who incidentially are of the same blood, and their supporters. Probably, parties would have preferred judicial settlement, but until the 1979 Constitution came into force, the courts had no jurisdiction in chieftaincy matters. ${ }^{78}$ The only alternative left for government to resolve any impending crisis was to set up an inquiry into the matter. Examples of such inquiries are the Inquiry into Adun Clan Headship Dispute 1972, Inquiry into Obong of Calabar Dispute 1971, Inquiry into Oniong Headship Dispute 1972, Internal Inquiry into the Selection of an Alafin of Oyo 1968, Judicial Commission of Inquiry into the Elemure of Emure Ekiti Chieftaincy Declaration 1975, Deji of Akure Commission of Inquiry 1975 and so on.

It is unfortunate that in spite of these inquiries, chieftaincy disputes still continue to arise even in those places where inquiries had been constituted before. The reason one can possibly adduce is the fact that governments decisions on the findings of inquiries are sometimes politicised, a situation which leaves one side still unsatisfied. That side would normally wait until government is changed before it starts agitation again. It appears that since 1979, when chieftaincy matters have been taken to courts, inquiries in this area have greatly reduced in number.

\section{Disaster and Civil Disturbances Inquiries}

These are inquiries set up to investigate the causes of disasters and civil disturbances. The government is always quick in doing this because such disasters normally involve loss of lives and properties, while civil disturbances lead to chaos and anarchy and the breakdown of law and order in the society. Examples of disaster inquiries are the Commission of Inquiry into the Building Disaster at Oremehi, Ibadan 1971, Langalaga Train Accident Tribunal of Inquiry 1971, Tribunal of Inquiry into the Republic Building Fire Incident 1982, University of If e Hostel Project Tribunal of Inquiry 1976 and so on.

Examples of civil disturbances inquiries are the Commission of Inquiry into the Disorders in the Eastern Provinces of Nigeria 1949, Commission of Inquiry into the Civil Disturbances in some parts of Wester State of Nigeria 1968, Kano Disturbances Tribunal of Inquiry 1981, Tribunal of Inquiry into Universities Crisis 1978, University of Ibadan Commission of Inquiry 1971, Tribunal of Inquiry on the University of Ife Students Incident 1981, Inquiry into the Communal Disturbances in Oranmiyan Central Local Government Area 1981 and so on. 


\section{Financial Impropriety Inquiries}

These are inquiries set up to investigate allegations of financial mismanagement in any government department or corporation or government financed projects. One may wonder why such matters are not handled by the security forces like the police, but when it is realised that such allegations are normally against top government functionaries, it would not be a surprise. An investigation by the police may be politically unwise, but for probity; such are better left for inquiries which may recommend internal administrative solution.

Allegations of financial impropriety of removing the fund belonging to the Nigerian National Petroleum Corporation (NNPC) from its accounts in a bank in England, and depositing it into a private account led to the Tribunal of Inquiry into Crude Oil Sales $1980 .^{79}$ Also allegations of fraud and financial impropriety led to Commission of Inquiry into the African Continental Bank 1956, Panel of Inquiry into the Purchase of British Leyland Buses by the Secretariat of FESTAC 1978 and Tribunal of Inquiry into the Administration and Financial Management of Ajeromi, Ikeja, Mushin and Agege Councils 1960. Others are Tribunal of Inquiry into the Finances of FESTAC 1976, Apapa Road Project Tribunal of Inquiry 1970, Commission of Inquiry into some Corporations in the Western Nigeria 1962 and so on.

Inquiries generally bother on sensitive political issue, which if not well handled, could bring down a government. The government realises this, hence those people whose findings will be respected are always enpanelled to conduct the inquiries. It is the practice to have a Judge (serving or retired) as the chairman, supported by experienced administrators or members of the public.

There have been criticisms of making judges, especially those who are still serving, as chairmen of inquiries. ${ }^{80}$ Apart from the fact that such exercise takes them off their normal judicial functions in courts, thereby leading to court congestion, their impartial image may be dented by involving them in matters which are political in nature. Critics therefore agree that judges should be exempted from inquiries; and if the need arises, then, retired judges should be made use of. Obafemi Awolowo University 1987, p. 300; Proceedings of All Nigeria Judges Conference 1982, pp. 30-32. 


\section{Conclusion}

The above shows a panoramic view on the characterisation and classification of tribunals and inquiries as we have them in Nigeria as of today. The classification is not sancrosant as some tribunals and inquiries may come under more than one classification. Irrespective of this they are still distinct and different from the others.

One problem that has confronted this writer is the determination of the number of tribunals and inquiries that are present in the country. As at today, there are thirty-one authorities that exercise power in setting up these bodies. While those set up by the Federal Government are easily known because of their prominence, those in the States are not easily accessible. Everyday, ministers and commissioners, exercising power under various statutes, constitute tribunals in their ministries, which are not publicised. Unlike in advanced countries, like Britain, where it is easily possible to know the number of tribunals and inquiries already in existence, to embark on such exercise in Nigeria is an herculian task.

A researcher is likely to face the wrath of the bureaucrats in trying to collate those tribunals and inquiries in various states, because of their sensitive nature. If the governments are however interested in improving the administration, all tribunals and inquiries should be made available for evaluation.

Prof. P. Oluyede has suggested the setting up of a Council of Tribunals, like in Britain, to organise the tribunals and inquiries in Nigeria. ${ }^{81}$ This may be a long term plan, since the problems encountered now are not alarming as what motivated the Council on Tribunals in England. ${ }^{82}$ With the use of the constitutional provisions, tribunals and inquiries are kept in check. What is of urgent importance now is the availability of the reports of the various tribunals and inquiries. They should be made available in designated national archives rather than being locked up in the cabinet offices.

One thing worthy of mention is the drastically reduced number of inquiries since 1983 when the military took over government from the civilian regime. The only possible reason is the firm control of government by the military as opposed to the weak, inapt civilian regime of 1979-1983 where corruption and embezzlement led to fire disasters which caused many inquiries to be constituted. If the military regime could be blamed at all, it is for the proliferation of 'judicial' tribunals.

81

82

P.A. Oluyede, Nigerian Administrative Law, University Press Ltd. 1986, p. 234

See H.W.R. Wade, Administrative Law, 4th Edition, p. 823; J.F. Garner, Administrative Law, 4th Edition, p. 201. 
Tribunals and inquiries will continue to be used by the administration in its effort to rule effectively and efficiently. This should, however, not be allowed to overshadow the rights and interests of the citizens, on behalf of and for whom government sets them up, otherwise the exercise will not be worth it. 


\title{
Characterisation and Classification of Tribunals and Inquiries in Nigeria
}

\author{
By M. Olu Adediran
}

Writing on characterisation and classification of tribunals and inquiries in Nigeria is like embarking on a hazardous journey, in which the path is full of mines; one only hopes that one would arrive at one's destination, in spite of the risk of injuries. This statement appears discouraging, but it candidly represents the truth about tribunals and inquiries in Nigeria. Instead of getting a clear, well defined system as in Britain, from where Nigeria copies the system, what is found is a proliferation of unclear, untidy and sometimes muddled-up bodies called "tribunals" or "inquiries" or "panels" or "commissions" or "committees", with the words used interchangeably even when what the body is intended to do is completely the opposite.

One major reason for this untidy situation is not the paucity of ideas of administrators but the unsteady political atmosphere in the country, which accounts for unsteady policies and the resultant confusion. It is a common feature for new governments to dismantle bodies set up by the previous regimes on the grounds of improvement, but to end by setting up other untidy bodies, that may later be equally dismantled by a succeeding government. 